Institute of $\mathbf{F}_{\text {ood and }} \mathbf{A}_{\text {gricultural }} \mathbf{S}_{\text {ciences }}$

\title{
2003 Handbook of Employment Regulations Affecting Florida Farm Employers and Workers: Work Opportunity Tax Credits (WOTC) Federal 1
}

\author{
Leo C. Polopolus, Michael T. Olexa, Fritz Roka, and Carol Fountain ${ }^{2}$
}

\section{Purpose}

Program provides tax credits for employers who hire certain targeted categories of individuals.

\section{Program}

In 1996, Congress created the Work Opportunity Tax Credit (WOTC) program as part of the Small Business Job Protection Act. This program replaces the Targeted Jobs Tax Credit (TJTC) program which expired at the end of 1994.

With the new WOTC program, employers who hire certain targeted categories of individuals will be eligible for tax credits. In most cases, the tax credit will be thirty-five percent of the first $\$ 6,000$ in wages for targeted employee.

\section{Targeted Categories of Individuals}

- Referrals from vocational rehabilitation.

- Ex felons.

- Food stamp recipients.

- Children whose parents are on welfare.

Tax credits are also available for employers who hire certain economically disadvantaged youths during any 90-day period beginning May 1 st and September 15th and for persons receiving state assistance with minor children, youths living in empowerment zones or enterprise communities, and economically disadvantaged youths.

\footnotetext{
1. This is EDIS document FE421, a publication of the Department of Food and Resource Economics, Florida Cooperative Extension Service, Institute of Food and Agricultural Sciences, University of Florida, Gainesville, FL. Published July 2003. This information is included in Circular 1200, Handbook of Employment Regulations Affecting Florida Farm Employers and Workers. First published February 1992 as Circular 1043 . Revised December 2002 as Circular 1200. Please visit the EDIS website at http://edis.ifas.ufl.edu.

2. Leo C. Polopolus, Professor Emeritus, Department of Food and Resource Economics, University of Florida, Gainesville, FL; Michael T. Olexa, Professor, Department of Food and Resource Economics, University of Florida, Gainesville, FL; Fritz Roka, Associate Professor, Department of Food and Resource Economics, Southwest Florida Research and Education Center, Immokalee, FL; and Carol Fountain, Assistant Editor, Department of Food and Resource Economics, University of Florida, Gainesville, FL; Florida Cooperative Extension Service, Institute of Food and Agricultural Sciences, University of Florida, Gainesville, FL.

This document is designed to provide accurate, current, and authoritative information on the subject. However, since the laws, administrative rulings, and court decisions on which it is based are subject to constant revision, portions of this publication could become outdated at any time. This publication is distributed with the understanding that the authors are not engaged in rendering legal or other professional advice, and the information contained herein should not be regarded as a substitute for professional advice. For these reasons, the utilization of these materials by any person constitutes an agreement to hold harmless the authors, the Institute of Food and Agricultural Sciences, and the University of Florida for any liability claims, damages, or expenses that may be incurred by any person as a result of reference to or reliance on the information contained in this publication.
}

The Institute of Food and Agricultural Sciences is an equal opportunity/affirmative action employer authorized to provide research, educational information and other services only to individuals and institutions that function without regard to race, color, sex, age, handicap, or national origin. For information on obtaining other extension publications, contact your county Cooperative Extension Service office. Florida Cooperative Extension Service/Institute of Food and Agricultural Sciences/University of Florida/Christine Taylor Waddill, Dean. 


\section{Determining Who Qualifies for Program}

To determine if an individual is a member of a targeted group, the U.S. Internal Revenue Service (IRS) has developed Form 8850, "Work Opportunity Credit Pre-Screening Notice and Certification Requests." Call the IRS at 1(800) 829-3676 for ordering Form 8850.

\section{Using Form 8850}

- If employers believe that any new hire is a member of a target group, they should complete Form 8850 on or before the day the job is offered to the applicant.

- Both the employer and applicant should sign Form 8850 and the employer must forward it to the state employment service office within three weeks after the applicant begins work.

- The employment service then reviews Form 8850 and determines whether the applicant is a member of a target group.

- If eligible, the state employment service certifies the applicant.

\section{Other Information}

- Labor Relations Bulletin No. 512, Florida Fruit and Vegetable Association, Orlando, FL, October 31, 1996.

\section{Responsible Agency (Tax Credit)}

U.S. Department of the Treasury

Internal Revenue Service

Washington, DC 20224

http://www.irs.gov

\section{Responsible Agency (Certification)}

Florida Agency for Workforce Innovation

Work Opportunity Tax Credit
325 John Knox Road, Suite 101, Bldg L

Tallahassee, FL 32303

(850) 921-3299

http://www.floridajobs.org/wotc/index.htm

For local offices, see telephone directory under

- Florida, State of

- Business and Professional Regulation, Department of

- Florida, Jobs and Benefits Center 